\title{
REVIEW
}

\section{Gene expression and hypoxia in breast cancer}

\author{
Elena Favaro ${ }^{\dagger}$, Simon Lord ${ }^{\dagger}$, Adrian L Harris and Francesca M Buffa*
}

\begin{abstract}
Hypoxia is a feature of most solid tumors and is associated with poor prognosis in several cancer types, including breast cancer. The master regulator of the hypoxic response is the Hypoxia-inducible factor $1 a$ (HIF-1a). It is becoming clear that HIF-1 a expression alone is not a reliable marker of tumor response to hypoxia, and recent studies have focused on determining gene and microRNA (miRNA) signatures for this complex process. The results of these studies are likely to pave the way towards the development of a robust hypoxia signature for breast and other cancers that will be useful for diagnosis and therapy. In this review, we outline the existing markers of hypoxia and recently identified gene and miRNA expression signatures, and discuss their potential as prognostic and predictive biomarkers. We also highlight how the hypoxia response is being targeted in the development of cancer therapies.
\end{abstract}

\section{Hypoxia is linked to poor cancer outcome}

Abnormally low levels of oxygen in cells, known as hypoxia, characterize most solid tumors. Hypoxia is associated with malignant progression, invasion, angiogenesis, changes in metabolism and increased risk of metastasis. It also severely affects treatment outcome because hypoxic tumors are usually resistant to radiotherapy and chemotherapy [1-4]. Up to $60 \%$ of locally advanced solid tumors exhibit hypoxic $\left(1 \% \mathrm{O}_{2}\right.$ or less, compared to 2 to $9 \% \mathrm{O}_{2}$ in the adjacent tissue) and/or anoxic (that is, no measurable oxygen, $<0.01 \% \mathrm{O}_{2}$ ) areas throughout the tumor mass. Studies in breast, uterine cervix and head and neck cancers suggest that the extent of hypoxia is independent of tumor stage, size, histology or grade [5].

†These authors contributed equally to this work

*Correspondence: francesca.buffa@imm.ox.ac.uk

The Weatherall Institute of Molecular Medicine, Department of Oncology, University of Oxford, Oxford OX3 9DS, UK
Hypoxia is caused by several factors: inadequate vascularization (tumor angiogenesis is often characterized by aberrant vessels that have altered perfusion); an increase in diffusion distances that is associated with tumor expansion (oxygen has to travel further to oxygenate tumor cells because of uncontrolled tumor growth); and tumor or therapy-related anemia (caused by reduced oxygen transport capacity) [5]. Cancer cells can adapt to a hostile, low-oxygen environment and this contributes to their malignancy and aggressive phenotype. This adaptation is governed by many factors, including transcriptional and post-transcriptional changes in gene expression. In this respect, up to $1.5 \%$ of the human genome is estimated to be transcriptionally responsive to hypoxia [6].

Several studies have attempted to characterize the tumor response to hypoxia and its prognostic implications. In particular, recent studies have identified gene and microRNA (miRNA) expression signatures (that is, lists of regulated genes or miRNAs) that are characteristic of this response. Here, we discuss these studies and focus on breast cancer as a type of cancer in which hypoxia has been shown to have clinical implications [5]. We then discuss the use of these signatures in attempts to identify predictive markers of disease. We also review the current approaches for targeting the master regulator of the hypoxic response, HIF- $1 \alpha$, in cancer treatments and the potential use of miRNA and gene signatures in this context.

\section{HIF, the hypoxia response and prognosis}

The master transcriptional regulators of the hypoxic response are represented by the family of hypoxiainducible factors. HIFs are heterodimers formed by an oxygen- and growth-factor-sensitive subunit $\alpha$ and a constitutively expressed subunit $\beta[7,8]$. In normoxic cells, the $\alpha$ subunit is recognized by and forms a complex with the von Hippel-Lindau protein ( $\mathrm{pVHL}$ ), which mediates its ubiquitination and degradation by the proteasome. In hypoxic cells, the $\alpha$ subunit is stabilized, it translocates to the nucleus where it dimerizes with the $\beta$ subunit and activates the transcription of target genes by binding to the hypoxic-response elements (HREs) present in their promoter region $[7,8]$. There are three isoforms of the $\alpha$ subunit, HIF- $1 \alpha$, HIF- $2 \alpha$ and HIF- $3 \alpha$, 
and one $\beta$ subunit, HIF- $1 \beta$. HIF- $1 \alpha$ is the isoform most ubiquitously expressed in cells, whereas HIF- $2 \alpha$ and HIF- $3 \alpha$ are expressed in a tissue-specific manner. HIF- $2 \alpha$ is found mainly in endothelium, liver, lung and kidney, where it acts like HIF- $1 \alpha$ on target genes. HIF- $3 \alpha$ is highly expressed in thymus, cerebellum and cornea, where it acts in a dominant-negative fashion to inhibit HIF- $1 \alpha$ and HIF- $2 \alpha$ (for a review, see [9]).

HIF-1 regulates key aspects of cancer biology, including cell proliferation and survival - for example, through regulation of Cyclin-dependent kinase inhibitor 1A (CDKN1A) and B-cell lymphoma $2(\mathrm{Bcl} 2)$ /adenovirus E1B $19 \mathrm{kDa}$ protein-interacting protein 3 (BNIP3); metabolism - for example, through Glucose transporter1 (GLUT1), GLUT3, Lactate dehydrogenase A (LDHA) and Pyruvate dehydrogenase kinase 1 (PDK1); $\mathrm{pH}$ regulation, through Carbonic anhydrase 9 (CAIX); invasion and metastasis, through $\mathrm{C}-\mathrm{X}-\mathrm{C}$ chemokine receptor type 4 (CXCR4) and Mesenchymal-epithelial transition factor (c-MET); angiogenesis, through Vascular endothelial growth factor A (VEGF-A); and stem cell maintenance, through Octamer-binding transcription factor 4 (OCT4) (Figure 1) [10]. In particular, GLUT1 and GLUT3 are transporters that are involved in the uptake of glucose, the main source of ATP generation through glycolysis in tumor cells. HIF-1 can induce many of the enzymes in this metabolic pathway, which culminates with the conversion of pyruvate into lactate by LDHA [11]. CAIX is a carbonic anhydrase located on the plasma membrane that hydrates $\mathrm{CO}_{2}$ to form $\mathrm{H}^{+}$and $\mathrm{HCO}_{3}-$ extracellularly [12]. The secretion of VEGF by hypoxic cells stimulates endothelial cell proliferation and leads to the formation of new vessels from pre-existing ones (that is, angiogenesis), to provide additional perfusion [13].

Tumor type has an important bearing on hypoxia response; in breast cancer, evidence suggests that the expression of $H I F-1 \alpha$ and its targets are key determinants of prognosis. High HIF-1 $\alpha$ expression has been associated with poorer prognosis in several studies (Table 1) and a recent meta-analysis confirmed this [3]. CAIX upregulation has also been associated with aggressive features and poor overall and relapse-free survival [14-16]. High expression of the HIF- $1 \alpha$ target gene VEGF has also been associated with poor prognosis [17-19]. GLUT1 upregulation has been associated with increased risk of recurrence, higher-grade tumors and proliferation [20], and the expression of this gene is associated with perinecrotic (in close proximity to the necrotic core) HIF-1 $\alpha$ expression [21]. Increased expression of Lactate dehydrogenase-5 $(L D H-5)$ has been associated with poor prognosis in endometrial, colorectal, head and neck and non-smallcell lung cancer [22-26], and the expression of this gene in breast cancer has been linked to HIF-1 $\alpha$ expression [27]. Interestingly, Rademakers et al. [28] described a strictly cytoplasmic expression pattern for $L D H-5$ in head and neck carcinomas, which showed a strong correlation with hypoxia. On the other hand, Koukourakis and colleagues [22-27] have repeatedly described a mixed cytoplasmic and nuclear expression pattern for $L D H-5$ in different types of tumor, including head and neck cancer. Nuclear $L D H-5$ reactivity was linked with high $H I F-1 \alpha$ expression, poorer survival and more aggressive tumors $[23,24]$, but its biological significance is still unknown.

Other hypoxia signaling pathways have also been identified; examples are pathways activated by the mammalian target of rapamycin (mTOR) kinase and independent signals regulated by the unfolded protein response (UPR) in the adaptive response to low $\mathrm{O}_{2}$ conditions. In particular, mTOR is a sensor of metabolic signals that can influence cell survival and growth through changes in several signaling pathways that are involved in protein synthesis, autophagy, apoptosis and metabolism [29]. Intriguingly, mTOR and HIF1 are reciprocally regulated, meaning that the deriving signaling pathways cannot be considered totally independent. Specifically, HIF1- $\alpha$ can inhibit mTOR through its targets Regulated in development and DNA damage responses 1 (REDD1) and BNIP3 $[30,31]$, whereas mTOR inhibition can result in increased HIF1- $\alpha$ translation, resulting in a regulatory loop [32]. Hypoxia, as a negative regulator of mTOR signaling, could potentially act as a suppressor of tumor growth, but recent evidence suggests that this response to hypoxia is less pronounced in tumor cells than in normal cells, especially when the hypoxia is moderate $\left(1 \% \mathrm{O}_{2}\right)$. Conversely, in the presence of more severe $\left(\leq 0.1 \% \mathrm{O}_{2}\right)$ or prolonged hypoxia, protein synthesis and proliferation are inhibited in most cells as a possible way to preserve energy [29].

\section{Hypoxia and treatment resistance}

Although there is still a paucity of good-sized clinical studies and there have been discrepancies between findings, a tendency of hypoxic tumor cells to be drugand radio-resistant has been identified [33]. Mechanisms of resistance include lack of oxidation of DNA free radicals by $\mathrm{O}_{2}$ (giving rise to resistance to ionizing radiation and antibiotics that induce DNA breaks), cell cycle arrest (giving rise to drug resistance), compromised drug exposure because distance from vasculature is increased (causing drug resistance) and extracellular acidification (also leading to drug resistance) (reviewed in [34]). HIF- $1 \alpha$ activation has also been associated with resistance to endocrine therapy and chemotherapy [35].

In a study involving 187 breast cancer patients treated with either neoadjuvant epirubicin chemotherapy or combined epirubicin and tamoxifen, both HIF- $1 \alpha$ and its target CAIX were associated with treatment resistance [36]. A further study of 114 breast cancers, which were 


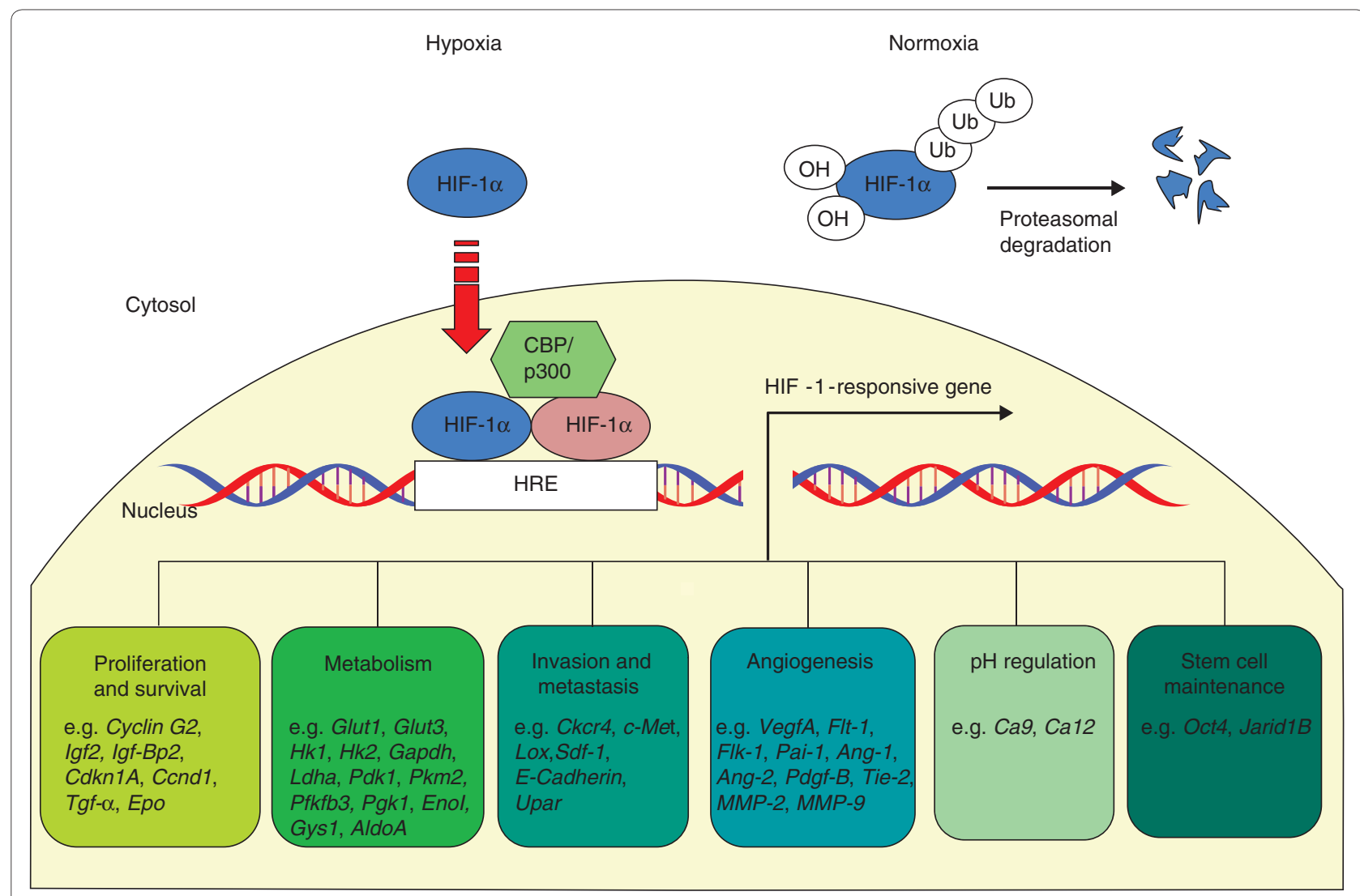

Figure 1. HIF-1 a regulation in normoxic and hypoxic conditions and a selection of the genes, grouped by biological function, that are directly regulated by HIF-1a. Under normoxic conditions, the subunit HIF-1a is hydroxylized and rapidly degraded by ubiquitin-proteasome degradation. Under hypoxic conditions, HIF-1a is stabilized and is translocated to the nucleus. There, it binds to the subunit HIF-1 $1 \beta$ and the co-activator p300 and activates the transcription of target genes that are involved in several cellular processes, including proliferation, survival, metabolism, angiogenesis, invasion and metastasis, pH regulation and stem cell maintenance. Abbreviations: ANG-1, Angiopoietin-1; CA9, Carbonic anhydrase 9; CBP, CREB binding protein; CCND1, cyclin D1; CKCR4, C-X-C chemokine receptor type 4; C-MET, Mesenchymal-epithelial transition factor; ENOI, Enolase I; EPO, Erythropoietin; FLK-1, Fetal liver kinase-1; FLT-1, FMS-like tyrosine kinase-1; GAPDH, Glyceraldehyde 3-phosphate dehydrogenase; GYS1,Glycogen synthase 1; HK1, Hexokinase 1; HRE, hypoxic-response element; IGF2, Insulin-like growth factor 2; IGF-BP2, IGF-binding protein 2; JARID 1B, Jumonji AT-rich interactive domain 1B; LOX, Lysyl oxidase; MMP-2, Matrix metalloproteinase 2; OCT4, Octamer-binding transcription factor 4; PAI-1,

Plasminogen activator inhibitor-1; PDGF-B, Platelet-derived growth factor-B; PDK1, Pyruvate dehydrogenase kinase 1; PFKFB3, 6-phosphofructo-2-kinase/ fructose-2,6-biphosphatase 3; PGK1, Phosphoglycerate kinase 1; PKM2, Pyruvate kinase M2; SDF-1, Stromal-derived factor 1; TGF-a, Transforming growth factor a; TIE-2, Tie-like receptor tyrosine kinase 2; Ub, Ubiquitin; UPAR, Urokinase plasminogen activator receptor.

treated preoperatively with aromatase inhibitor, showed that HIF- $1 \alpha$ expression was an independent factor that was associated with treatment resistance [37]. This concurs with earlier evidence that tumors with low CAIX expression benefit from adjuvant endocrine or chemotherapy treatment [38]. In a study of 45 malignant astrocytomas, elevated CAIX was associated with poor response to combined treatment with bevacizumab and irinotecan [39]. Elevated serum CAIX has been associated with reduced progression-free survival in metastatic breast cancer patients treated with trastuzumab [40].

The HIF target GLUT1 exerts a cytoprotective effect by allowing increased glucose transport into hypoxic cancer cells, and its overexpression is common in breast cancer [41]. In vitro studies with antibodies that block GLUT1 function, in conjunction with cytotoxic agents commonly used in breast cancer treatment, abolish proliferation in cancer cell lines, indicating a role for GLUT1 in treatment resistance [42].The HIF target gene VEGF has been associated with resistance to both hormonal and chemotherapies for breast cancer [43]. There is a lack of general agreement on the effect of antiangiogenic therapy on tumor perfusion and hypoxia (reviewed in [44]), but some evidence suggests that antiangiogenic agents might reduce tumor oxygenation, inducing the activation of HIF- 1 and its downstream targets and subsequently leading to tumor escape $[45,46]$.

These studies highlight the importance of assessing hypoxia. Although several studies have been performed on single genes, we could identify only one study that 
Table 1. Prognostic studies in breast cancer looking at HIF-1a and HIF-2a overexpression detected via immunohistochemistry

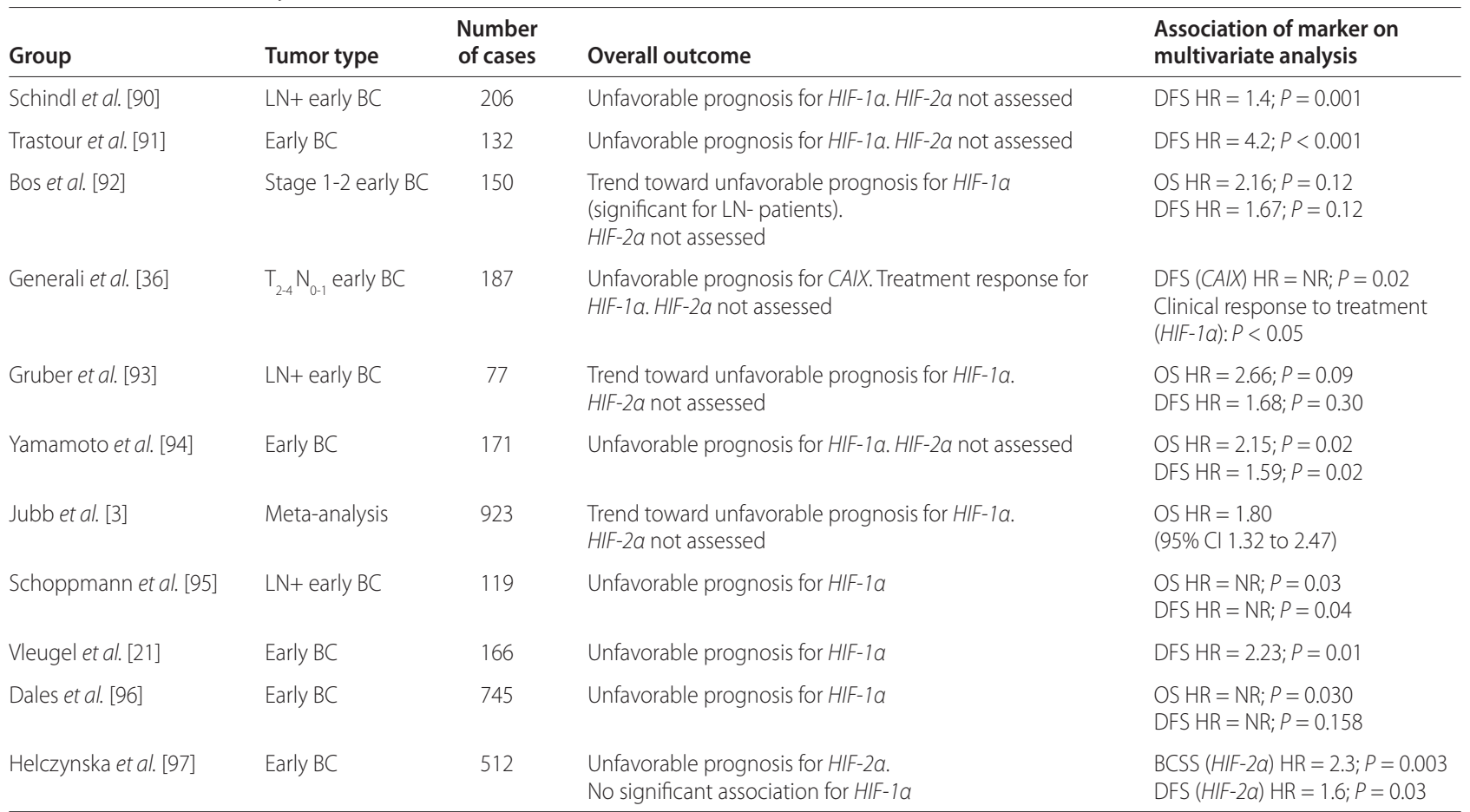

BC, breast cancer; BCSS, breast cancer-specific survival; $\mathrm{Cl}$, confidence interval; LN+, lymph node positive; LN-, lymph node negative; DFS, disease free survival; HR, hazard ratio; NR, not reported; OS, overall survival.

looked at the role of a hypoxia gene-expression signature in treatment response [47]. This highlights the need for more comprehensive studies to investigate the expression of multiple hypoxia markers and of gene and miRNA signatures before and after treatment. Careful pharmacokinetic and pharmacodynamic analyses are also needed to derive markers of treatment efficacy or resistance. The finding of such research could not only allow the selection of patients who would benefit most from treatments, but could also avoid the use of specific treatments in cases where they might be detrimental [45].

\section{Targeting hypoxia in cancer treatment}

Given the role of HIF-1 in resistance to cancer treatments, the inhibition of this protein is an attractive therapeutic approach (Table 2). In vitro data suggest that small molecule inhibitors of HIF- $1 \alpha$ in combination with adenovirus-delivered gene therapy might reverse the hypoxic chemo-resistance of cancer cells [48]. Concerted attempts have thus been made to identify HIF-1 inhibitors using high-throughput screens. A better understanding of the HIF activation pathway could inform the choice of therapy, the individualization of treatments and the development of novel agents. Several of the cancer treatments already licensed for use, including the Topoisomerase 1 inhibitor topotecan, have been shown to inhibit
HIF- $1 \alpha$ protein accumulation in cell lines and xenograft studies $[49,50]$. It may be that, in the clinical setting, such agents will have synergy with drugs such as bevacizumab, which is thought to cause treatment-induced hypoxia and subsequent HIF- $1 \alpha$ activation that lead to drug resistance [46].

Several novel compounds are under investigation. Bortezomib is a proteasome inhibitor already approved for the treatment of hematological malignancies. A pharmacodynamic study in a metastatic colorectal cancer phase II trial observed downregulation of CAIX in response to bortezomib, suggesting a disrupted hypoxia response to this compound [51]. Another novel compound, PX-478, inhibits HIF- $1 \alpha$ transcription and HIF- $1 \alpha$ protein levels in a p53- and PVHL-independent manner [52]. YC-1, a synthetic compound, has been widely used in the laboratory setting to investigate the physiological and pathological role of HIF. In cancer cell lines, YC-1 inhibits HIF through factor inhibiting HIF (FIH)-dependent inactivation of the carboxy-terminal transactivation domain (CAD) of HIF-1 $\alpha$ [53].

A high-throughput cell-based screen has shown that another compound, DJ12, inhibits HIF-inducible transcription [54]. Another approach demonstrated that ascorbate increases the activity of prolyl hydroxylase enzymes, leading to HIF downregulation, in cells treated 
Table 2. HIF-1a inhibitors and proposed mechanisms of action

\begin{tabular}{|c|c|c|c|}
\hline Name & Class of drug & Mechanism of action & Current status as a cancer therapy \\
\hline Digoxin & Cardiac glycoside & $\begin{array}{l}\text { Inhibits HIF-1-dependent gene transcription } \\
\text { but precise mechanism unclear }\end{array}$ & $\begin{array}{l}\text { Under evaluation in early phase trials in lung and } \\
\text { prostate cancer (www.clinicaltrials.gov) }\end{array}$ \\
\hline AFP464 & $\begin{array}{l}\text { Aminoflavine prodrug } \\
\text { (DNA-damaging agent) }\end{array}$ & $\begin{array}{l}\text { Inhibition of HIF-1a mRNA expression but } \\
\text { precise mechanism unclear }\end{array}$ & $\begin{array}{l}\text { Early evidence of clinical activity in heavily pre-treated } \\
\text { advanced solid tumors in phase } 1 \text { trials [98] }\end{array}$ \\
\hline $\begin{array}{l}\text { Topotecan and } \\
\text { EZN-2208 }\end{array}$ & $\begin{array}{l}\text { Topoisomerase-1 } \\
\text { inhibitors and cytotoxic } \\
\text { agents }\end{array}$ & $\begin{array}{l}\text { Inhibition of HIF-1a-mediated protein } \\
\text { translation by a Top1-dependent but } \\
\text { DNA damage-independent mechanism }\end{array}$ & $\begin{array}{l}\text { Topotecan licensed for treatment of advanced lung, } \\
\text { cervical and ovarian cancer. } \\
\text { EZN-2208 undergoing evaluation in phase } 2 \text { trials for } \\
\text { treatment of metastatic breast and colorectal cancer } \\
\text { (www.clinicaltrials.gov) }\end{array}$ \\
\hline $\begin{array}{l}\text { Doxorubicin and } \\
\text { daunorubicin }\end{array}$ & Anthracyclines & Inhibits binding of HIF-1a to the HRE sequence & $\begin{array}{l}\text { Anthracyclines licensed to treat breast, bladder and lung } \\
\text { cancer, several hematological malignancies and sarcoma }\end{array}$ \\
\hline Echinomycin & Quinoxaline antibiotic & Inhibits HIF-1 binding to DNA & $\begin{array}{l}\text { Minimal evidence of efficacy in the treatment of solid } \\
\text { tumors in phase } 2 \text { trials [99] }\end{array}$ \\
\hline Everolimus & mTOR inhibitor & Inhibits HIF-1a target protein translation & Licensed for treatment of advanced renal cancer \\
\hline Bortezomib & Proteasome inhibitor & $\begin{array}{l}\text { Repression of HIF-1a transcriptional activity } \\
\text { by inhibiting recruitment of the p300 } \\
\text { co-activator by FIH }\end{array}$ & $\begin{array}{l}\text { Licensed for treatment of multiple myeloma. Under } \\
\text { evaluation in early-phase trials in solid tumors }\end{array}$ \\
\hline $\begin{array}{l}\text { Geldanamycin or } \\
\text { tanespimycin }\end{array}$ & HSP-90 inhibitor & $\begin{array}{l}\text { Failure to recruit HIF-1 a cofactors for } \\
\text { downstream protein transcription }\end{array}$ & $\begin{array}{l}\text { Early evidence of clinical activity in advanced solid and } \\
\text { hematological malignancies in early phase trials } \\
{[100,101]}\end{array}$ \\
\hline PX-478 & Melphalan derivative & $\begin{array}{l}\text { Inhibits HIF-1 a protein levels and HIF-1 } \\
\text { transcriptional activity in a p53- and pVHL- } \\
\text { independent manner }\end{array}$ & $\begin{array}{l}\text { Early evidence of clinical activity in advanced solid } \\
\text { tumors in a phase } 1 \text { trial [102] }\end{array}$ \\
\hline Compound DJ12 & & $\begin{array}{l}\text { Downregulates the mRNA of downstream } \\
\text { targets of HIF-a, inhibits HIF-1a transactivation } \\
\text { activity by blocking HIF-1a HRE-DNA binding }\end{array}$ & Preclinical \\
\hline YC-1 & $\begin{array}{l}\text { Synthetic } \\
\text { benzylindazole derivative }\end{array}$ & FIH-dependent inactivation of the CAD of HIF-1a & Pre-clinical \\
\hline
\end{tabular}

with anti-surface transferrin receptor (TFR) antibody [55]. The anti-HIF activity of two other novel anticancer drugs, AJM290 and AW464, has also been examined; both compounds inhibit HIF-1 $\alpha$ transcription at the CAD and DNA-binding domains, although they also inhibit HIF degradation [56].

Gene therapy that utilizes HIF-1 $\alpha$ expression and the promoter regions of its downstream target genes (that is, HREs) would be an attractive approach. This might allow the targeted delivery of anticancer agents to tumor tissue. For example, it has been shown that hypoxic cells can be targeted by combining a HIF-responsive promoter with an oncovirus that is armed with the interleukin-4 gene. Treatment of xenografts using this technique led to maintained tumor regression [57]. One group demonstrated that HIF- $1 \alpha$-based gene therapy can eradicate small EL-4 xenografts and also that this therapy augments the efficacy of the antiangiogenic agent angiostatin [58]. Nevertheless, the great variability in the level of hypoxia, and hence HIF-1 $\alpha$ expression, within a single tumor presents a challenge to such approaches.

\section{Methods for detecting hypoxia}

Methods that can reliably detect hypoxic tumors are crucial because of the roles of hypoxia in tumor prognosis and in resistance to specific treatments. Various methods are used to detect hypoxia in solid cancer tumors, but contrasting results have been reported [5]. $\mathrm{O}_{2}$ measurement with a polarographic $\mathrm{O}_{2}$ needle electrode is the most direct method, but it has limitations, including its invasiveness, its inability to represent the whole tumor, and the possibility that it can generate false positive determinations as a result of oxygen consumption by the electrodes. In the clinic, the assessment of hypoxia is moving towards the evaluation of endogenous and exogenous markers. Immunohistochemistry is widely used in patient biopsies, and this method can detect both endogenous and exogenous markers of hypoxia. Among the endogenous markers, particular interest has been paid to $H I F-1 \alpha$ and some of its target genes, including GLUT1, CAIX and VEGF. One limitation that is associated with these markers is their potential regulation by non-hypoxia-related factors (for example, $\mathrm{pH}$ or the concentrations of metabolites such as glucose and glutamine). Exogenous markers of hypoxia include nitroimidazole compounds derived from imidazole (for example, pimonidazole, 2-(2-nitro-1H-imidazol-1-yl)-N-(2,2,3,3,3pentafluoropropyl)-acetamide (EF5)). These compounds need to be systemically administered to patients and generate stable adducts with proteins in hypoxic 
conditions; these can be detected by the use of specific antibodies on tumor biopsies. The main limitations of these methods are their invasiveness (they are performed on tumor biopsies), non-representative sampling (the tumor can be very heterogeneous and biopsies can be non-representative of the whole tumor), and the inability to perform multiple evaluations so as to follow changes in tumor oxygenation after treatment [59].

A more recently developed technique for imaging hypoxic tumors that is now being implemented in the clinic is the use of nitroimidazole derivatives in combination with positron emission tomography (PET). Several derivatives of nitroimidazole are now being studied in order to identify the best tracer with high uptake and low toxicity [60,61]. Among these, ${ }^{18} \mathrm{~F}$-fluoromisonidazole ( $\left.{ }^{18} \mathrm{~F}-\mathrm{MISO}\right)$ is the most extensively studied, and it has an investigational new drug (IND) authorization from the Food and Drug Administration (FDA) as an investigational product for use in humans. Although the ${ }^{18} \mathrm{~F}$ MISO-PET technique is non-invasive and allows the serial imaging of hypoxia, the accumulation of ${ }^{18} \mathrm{~F}-\mathrm{MISO}$ in hypoxic tumors is relatively low. This results in a low signal-to-noise ratio and hence a poor contrast between hypoxic tumors and surrounding normal tissues (for a detailed review, see [62]).

The imaging of tumor hypoxia by blood oxygen leveldependent magnetic resonance imaging (BOLD MRI) is also being investigated. This modality relies on the detection of paramagnetic deoxyhemoglobin within red blood cells, and does not require administration of exogenous tracers. The main limitations of this technique are the fact that it does not measure tissue $\mathrm{pO}_{2}$ directly and could be influenced by blood flow, tumor perfusion and other vascular parameters.

In addition to these difficulties, it is becoming clear that assessing one single factor, such as HIF1, does not reflect the complexity of a tumor response to hypoxia, and hence is unlikely to be a reliable marker [3,5]. More comprehensive approaches for the detection and selection of hypoxic tumors for therapy have therefore been investigated.

\section{Gene signatures of hypoxia}

The identification by global expression analysis of multiple genes (that is, gene signatures) and pathways that are responsive to hypoxia might overcome most of the limitations of current markers and other detection methods. Such gene expression signatures also have the potential to reflect the complexity of the tumor hypoxia response. They could, therefore, be used to reveal the nature of the hypoxic response to a specific therapy in terms of gene networks and hence improve our understanding of mechanisms of resistance. This would enable not only the identification of prognostic and predictive markers but also the selection of novel targets for therapeutics.

Several groups have derived hypoxia gene expression profiles that have prognostic significance in breast cancer [47,63-67] (Table 3). For example, Winter et al. [47] defined an in vivo hypoxia 'metagene' (signature) in head and neck squamous cell carcinomas (HNSCCs) by clustering (that is, by finding) genes whose expression pattern was similar to that of a set of well-known hypoxia-regulated genes, including CAIX, GLUT1 and $V E G F$. The metagene contained 99 genes, several of which were previously described as hypoxia-responsive in vitro. These genes included Aldolase A (ALDOA), Glyceraldehyde 3-phosphate dehydrogenase (GAPDH), Placental growth factor $(P G F)$ and BNIP3 as well as some new genes that could play an important role in the hypoxic response in vivo, such as Metaxin 1 (MTX1), Breast cancer anti-estrogen resistance 1 (BCAR1), Proteasome subunit $\alpha$ type-7 (PSMA7) and Solute carrier organic anion transporter family member 1B3 (SLCO1B3). This signature proved to be prognostic in independent HNSCC and breast cancer series [47]. Some of these genes are being studied in ongoing follow-up studies. An example is Iron sulfur cluster scaffold homolog (ISCU), a gene that was downregulated in the hypoxia signature; this gene was subsequently found to be a target of the hypoxia-regulated $h s a-m i R-210$ and a good prognostic factor [68].Chi et al. [65] analyzed the gene expression profiles of mammary and renal tubular epithelial cells that were exposed to low $\mathrm{O}_{2}$ levels. They derived a signature called 'epithelial hypoxia signature' that presented coordinated variation in several human cancers. Of particular note, they found that a set of renal tumors could be stratified into two groups, one with high and one with low expression of the hypoxia-response genes. The high-hypoxia-response group included clear-cell renal cell carcinomas, which frequently present high levels of HIF- $1 \alpha$ and/or HIF- $2 \alpha$ because of the loss of functional pVHL. The signature could also differentiate between low- and high-signature-expression groups in a set of ovarian cancer samples and two different sets of breast cancer samples. In one of the breast cancer sets, Chi et al. [65] found a significant association between high expression of the hypoxia signature and mutation in p53, negative estrogen receptor status and high grade tumors. In all of these sample sets, those patients assigned to the high-expression group had the worse prognosis. Finally, Chi et al. [65] also showed that the generated signature was an independent predictor of poor prognosis, proving its potential in clinical decisionmaking. Seigneuric et al. [67] used the data from Chi et al.'s study [65] to distinguish gene signatures in human mammary epithelial cells that are associated with early (1, 3 and 6 hours) hypoxic exposure rather than late (after 
Table 3. Prognostic hypoxia gene expression signatures in breast cancer

\begin{tabular}{|c|c|c|c|}
\hline Study & Description and size of gene signature & Hazard ratio (HR) & $P$-value \\
\hline Chi et al. [65] & Signature of hypoxia upregulated genes in epithelial cells in vitro: 253 genes & $\begin{array}{l}\text { MFS HR }=2.164 \\
\text { Death HR }=2.387\end{array}$ & $\begin{array}{l}0.004 \\
0.003\end{array}$ \\
\hline Seigneuric et al. [67] & Early signature of hypoxia: 15 genes & DSS HR $=N R$ & $<0.05$ \\
\hline Winter et al. [47] & Signature of hypoxia-related genes in HNSCC: 99 genes & $\begin{array}{l}\text { NKI data set: } \\
\text { MFS HR }=2.83\end{array}$ & $<0.001$ \\
\hline Buffa et al. [63] & $\begin{array}{l}\text { Common signature of hypoxia-related genes in HNSCC and breast cancer } \\
\text { in vivo: } 51 \text { genes }\end{array}$ & $\begin{array}{l}\text { NKI data set: } \\
\text { MSF HR }=4.15 \\
\text { GSE2034 data set: } \\
\text { RFS HR = 3.22 } \\
\text { GSE3494 data set: } \\
\text { DSS HR }=3.16\end{array}$ & $\begin{array}{l}0.002 \\
0.001 \\
0.042\end{array}$ \\
\hline Buffa et al. [103] & $\begin{array}{l}\text { Reduced common signature of hypoxia-related genes in HNSCC and breast } \\
\text { cancer: NK genes }\end{array}$ & $\begin{array}{l}\text { NKI data set: } \\
\text { MSF HR = } 5.58(N K=3) \\
\text { GSE2034 data set: } \\
\text { RFS HR = 4.15 (NK = 10) } \\
\text { GSE3494 data set: } \\
\text { DSS HR = 4.27 }(N K=2)\end{array}$ & $\begin{array}{r}<0.001 \\
<0.001 \\
0.006\end{array}$ \\
\hline
\end{tabular}

DSS, disease-specific survival; GSE, genomic special event; MSF, metastasis-free survival; NK, number of genes; NKI, Netherlands Cancer Institute; NR, not reported; RFS, recurrence-free survival.

12 and 24 hours) hypoxic exposure. They showed that only the early-exposure gene signature had significant prognostic power, allowing the stratification of a cohort of patients with breast cancer into two groups: those with low expression of the early hypoxic response signature (better prognosis) and those with high expression of this signature (worse prognosis).

More recently, Buffa et al. [63] derived a hypoxia signature that is common to HNSCC and breast cancers. They used a meta-analysis approach to generate a more general and robust signature that might better reflect tumor response to hypoxia in vivo and be better suited for clinical use. They showed that a reduced metagene including as few as three genes (VEGFA, Solute carrier family 2 member 1 (SLC2A1; also known as GLUT1) and Phosphoglycerate mutase 1 (PGAM1)) had prognostic power similar to that of a large signature in independent breast cancer, HNSCC and lung cancer series. But they also validated a network-based approach that considers multiple hypoxia prototype genes, builds a co-expression network of hypoxia-related genes across clinical series, and then uses the network to generate biologically and clinically relevant hypotheses. For example, Buffa et al. [63] showed that genes involved in angiogenesis (VEGFA), glucose metabolism (SLC2A1, PGAM1, Enolase I (ENOI), $L D H A$, Triosephosphate isomerase II (TPII) and ALDOA) and cell cycling (CDKN3) were among those most likely to be over-expressed both in hypoxic HNSCC and hypoxic breast cancers. These genes could all contribute to global survival pathways triggered by hypoxia in vivo.

Despite cell-line diversity, the derivation of gene signatures using in vitro model systems can be powerful because some of the fundamental processes are conserved and clean experimental design can be easily applied. Conversely, the in vivo tumor system requires consideration of multiple cell types, microenvironmental changes and three-dimensional complexity. Approaches that integrate knowledge of gene function garnered from in vitro experiments with the analysis of expression in vivo might deliver signatures that better represent the hypoxia response that occurs in cancer.

Gene signatures reflect the hypoxic response at the transcriptional level, which is only part of the story of the overall effect of hypoxia. miRNA signatures are therefore under investigation as post-transcriptional regulators of the hypoxic response.

\section{miRNA signatures of hypoxia}

miRNAs are small non-coding RNAs that control gene expression post-transcriptionally by regulating mRNA translation and stability [69,70]. The expression of miRNAs in tumors and normal tissues has been compared, and the differences have been found to affect cellular processes, including proliferation, apoptosis and metabolism, with the miRNAs acting as either oncogenes or tumor suppressors [71,72]. Furthermore, changes in miRNA expression have been associated with clinicopathological features and disease outcome in different tumor types, including breast cancer [73-76].

Several hypoxia-inducible miRNAs have been identified and two studies have focused their attention on breast cancer $[77,78]$. Kulshreshtha et al. [78] compiled a list of miRNAs that were consistently upregulated across a panel of breast and colon cancer cell lines exposed to hypoxia. Moreover, several of the miRNAs that were included in this signature were also overexpressed in breast cancer and other solid tumors, suggesting that hypoxia could be a key factor in miRNA modulation in 


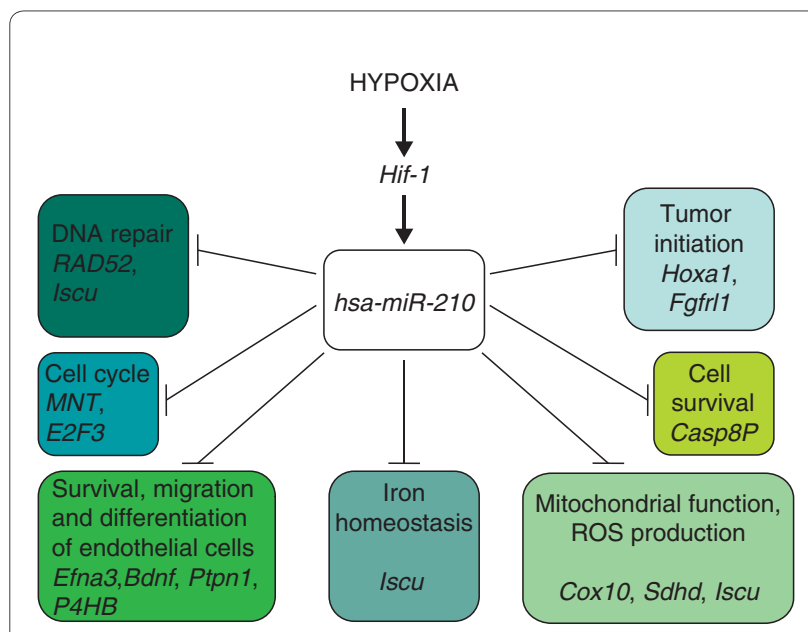

Figure 2. Cell functions modulated by hsa-miR-210 in hypoxia. See Table 4 for a full list of targets, full names and related references.

cancer [78]. The study by Camps et al. [77] generated a short list of miRNAs that were induced by hypoxia in a breast cancer cell line. The cells were grown under conditions of either normoxia $\left(21 \% \mathrm{O}_{2}\right)$ or hypoxia $(1 \%$ $\mathrm{O}_{2}$ ) for 16 hours. Among the list of 377 miRNAs analyzed, they found that only four were significantly upregulated in hypoxia, with only three showing a greater than two-fold induction. Among these, hsa-miR-210 appeared to be the most robustly and consistently upregulated. This miRNA has been validated as a HIF-1 target $[77,78]$ and its expression levels significantly correlated with a hypoxia gene expression signature in breast cancer [47], suggesting that it is also regulated by hypoxia in vivo. Furthermore, $h s a-m i R-210$ expression was prognostic in a study of 210 breast cancers [77].

Great effort is now being directed towards unveiling targets that contribute to tumor aggressiveness. Comparative analysis of hypoxia-regulated miRNAs using gene expression profiles might add valuable information to the interrogation of target-prediction algorithms. Several targets have been investigated to date (Figure 2 and Table 4) showing roles for hsa-miR-210 in cell-cycle regulation, apoptosis, iron accumulation, the production of reactive oxygen species, cell metabolism, DNA repair, tumor initiation, and the survival, migration and differentiation of endothelial cells (Figure 2) [68,79-87]. Of particular note, our group recently showed the major biological effects of miR-210 in targeting $I S C U$, all of which are likely to contribute to important phenotypes in cancer. By downregulating $I S C U, m i R-210$ decreases the activity of Kreb's cycle enzymes and mitochondrial function, contributes to an increase in free radical generation in hypoxia, increases cell survival under hypoxia, induces a switch to glycolysis in both normoxia
Table 4. $h s a-m i R-210$ validated targets

\begin{tabular}{|c|c|c|}
\hline $\begin{array}{l}\text { Gene } \\
\text { symbol }\end{array}$ & $\begin{array}{l}\text { Gene } \\
\text { name }\end{array}$ & Reference(s) \\
\hline EFNA3 & Ephrin-A3 & {$[81,104]$} \\
\hline NPTX1 & Neuronal pentraxin 1 & [104] \\
\hline E2F3 & E2F transcription factor 3 & [82] \\
\hline RAD52 & Rad52 homolog & {$[80]$} \\
\hline MNT & MAX-binding protein & [87] \\
\hline HOXA1 & HomeoboxA1 & [83] \\
\hline HOXA9 & Homeobox A9 & [83] \\
\hline FGFRL1 & Fibroblast growth factor-like 1 & {$[83,86]$} \\
\hline CASP8P & Caspase8-associated protein 2 & [84] \\
\hline$A C V R 1 B$ & Activin receptor $1 B$ & {$[105]$} \\
\hline BDNF & Brain-derived neurotrophic factor & [106] \\
\hline PTPN1 & Tyrosine-protein phosphatase non-receptor type 1 & [106] \\
\hline$P 4 H B$ & Protein disulphide isomerase & {$[106]$} \\
\hline GPDIL & Glycerol-3-phosphatase dehydrogenase 1-like & [106] \\
\hline ISCU & Iron sulfur cluster scaffold homolog & {$[68,107]$} \\
\hline $\operatorname{cox} 10$ & Cytochrome coxidase assembly protein & [108] \\
\hline SDHD & Succinate dehydrogenase complex subunit D & {$[85]$} \\
\hline
\end{tabular}

and hypoxia, and upregulates the iron uptake required for cell growth. Importantly, analysis of more than 900 patients with different tumor types, including breast cancer, showed that the suppression of ISCU was correlated with a worse prognosis [68].

Although most studies on miRNAs have focused their attention on $m i R-210$, other miRNAs could contribute to the hypoxic response. For example, experimental evidence suggests that miR-26 and miR-107 might have roles in cell survival in a low-oxygen environment [78]. A recent study has shown that $m i R-495$ is robustly upregulated in a subset of a breast cancer stem cell population, both in stabilized cancer cell lines and in primary cells [88], where it promotes colony formation and tumorigenesis. Moreover, miR-495 is involved in maintenance of the cancer stem cell phenotype, in invasion by suppression of E-cadherin, and in hypoxia resistance through modulation of the REDD1mTOR pathway.

Finally, the ability to detect miRNAs (for example, $h s a-$ $m i R-210$ ) in plasma and urine, as well as in tumor tissues, further increases the clinical potential of these small molecules [89].

Although this young field is undergoing rapid development, there are as yet no signatures that can be used in the clinical setting, but the results show that this area of research has great potential.

\section{Conclusions}

Hypoxia occurs in most solid tumors, and has been associated not only with malignant progression and poor 
prognosis but also with specific resistance to anti-cancer therapies. Many biomarkers have been suggested for hypoxia, but they all have limitations. Furthermore, it is unlikely that a single-gene biomarker will be sufficient to characterize the complexity of a tumor's response to hypoxia.

Several gene and miRNA expression signatures have also been suggested, and these have revealed commonalities and specificities of the hypoxia response in different experimental cancer systems both in vitro and in vivo. These signatures promise greater prognostic and therapeutic potential than single-gene markers, but the specific interactions between these signatures, the HIF response and responses to treatments remain unclear. A full understanding of these interactions is of paramount importance both when assigning the most beneficial treatment to patients and when designing new therapeutic strategies, such as combined modality treatments and multi-target or multiple-hit strategies. In this respect, the validation, optimization and assessment of these potential biomarkers in prospective clinical studies and randomized trials are increasingly needed to transform them into useful clinical tools.

\begin{abstract}
Abbreviations
AldoA, Aldolase A; BNIP3, BCL2/adenovirus E1B 19 kDa protein-interacting protein 3; CAD, carboxy-terminal transactivation domain; CAIX, Carbonic anhydrase 9; CDKN1A, Cyclin-dependent kinase inhibitor 1A; FIH, factor inhibiting HIF; GLUT1, Glucose transporter1; HIF-1a, Hypoxia-inducible factor 1a; HNSCC, head and neck squamous cell carcinoma; HRE, hypoxicresponse element; ISCU, Iron-sulfur cluster scaffold homolog; LDH-5, Lactate dehydrogenase-5; LDHA, Lactate dehydrogenase A; mTOR, mammalian target of rapamycin; miRNA, microRNA; PGAM1, Phosphoglycerate mutase 1; pVHL, von Hippel-Lindau protein; REDD1, Regulated in development and DNA damage responses 1; SLC2A1, Solute carrier family 2 member 1; VEGFA, Vascular endothelial growth factor $\mathrm{A}$
\end{abstract}

\section{Competing interests}

The authors declare that they have no competing interests.

\section{Authors' contributions}

EF, SL and FMB conducted a systematic review of the literature and drafted the manuscript. EF and SL prepared the tables and figures. FMB and ALH designed the study and revised the manuscript. All of the authors read and approved the final manuscript.

\section{Acknowledgements}

The authors would like to acknowledge support from GlaxoSmithKline, Cancer Research UK, the Oxford National Institute for Health Research (NIHR) Comprehensive Biomedical Research and Experimental Cancer Medicine Centers, the Breast Cancer Research Foundation, and the EU $6^{\text {th }}$ and $7^{\text {th }}$ Framework Programs.

Published: 26 August 2011

\section{References}

1. Fyles A, Milosevic M, Hedley D, Pintilie M, Levin W, Manchul L, Hill RP: Tumor hypoxia has independent predictor impact only in patients with nodenegative cervix cancer. J Clin Oncol 2002, 20:680-687.

2. Hockel M, Schlenger K, Aral B, Mitze M, Schaffer U, Vaupel P: Association between tumor hypoxia and malignant progression in advanced cancer of the uterine cervix. Cancer Res 1996, 56:4509-4515.

3. Jubb AM, Buffa FM, Harris AL: Assessment of tumour hypoxia for prediction of response to therapy and cancer prognosis. J Cell Mol Med 2010, 14:18-29.
4. Nordsmark M, Bentzen SM, Rudat V, Brizel D, Lartigau E, Stadler P, Becker A, Adam M, Molls M, Dunst J, Terris DJ, Overgaard J: Prognostic value of tumor oxygenation in 397 head and neck tumors after primary radiation therapy. An international multi-center study. Radiother Onco/ 2005, 77:18-24.

5. Vaupel P, Mayer A: Hypoxia in cancer: significance and impact on clinical outcome. Cancer Metastasis Rev 2007, 26:225-239.

6. Denko NC, Fontana LA, Hudson KM, Sutphin PD, Raychaudhuri S, Altman R, Giaccia AJ: Investigating hypoxic tumor physiology through gene expression patterns. Oncogene 2003, 22:5907-5914.

7. Ratcliffe PJ, O'Rourke JF, Maxwell PH, Pugh CW: Oxygen sensing, hypoxiainducible factor-1 and the regulation of mammalian gene expression. J Exp Biol 1998, 201:1153-1162.

8. Semenza GL: Hypoxia-inducible factor 1: master regulator of $\mathrm{O}_{2}$ homeostasis. Curr Opin Genet Dev 1998, 8:588-594.

9. Bertout JA, Patel SA, Simon MC: The impact of $\mathrm{O}_{2}$ availability on human cancer. Nat Rev Cancer 2008, 8:967-975.

10. Semenza GL: Defining the role of hypoxia-inducible factor 1 in cancer biology and therapeutics. Oncogene 2010, 29:625-634.

11. Semenza GL, Jiang BH, Leung SW, Passantino R, Concordet JP, Maire P, Giallongo A: Hypoxia response elements in the aldolase A, enolase 1, and lactate dehydrogenase $A$ gene promoters contain essential binding sites for hypoxia-inducible factor 1. J Biol Chem 1996, 271:32529-32537.

12. Wykoff CC, Beasley NJ, Watson PH, Turner KJ, Pastorek J, Sibtain A, Wilson GD, Turley H, Talks KL, Maxwell PH, Pugh CW, Ratcliffe PJ, Harris AL: Hypoxiainducible expression of tumor-associated carbonic anhydrases. Cancer Res 2000, 60:7075-7083.

13. Pugh CW, Ratcliffe PJ: Regulation of angiogenesis by hypoxia: role of the HIF system. Nat Med 2003, 9:677-684.

14. Brennan DJ, Jirstrom K, Kronblad A, Millikan RC, Landberg G, Duffy MJ, Ryden L, Gallagher WM, O'Brien SL: CAIX is an independent prognostic marker in premenopausal breast cancer patients with one to three positive lymph nodes and a putative marker of radiation resistance. Clin Cancer Res 2006, 12:6421-6431.

15. Chia SK, Wykoff CC, Watson PH, Han C, Leek RD, Pastorek J, Gatter KC, Ratcliffe $P$, Harris AL: Prognostic significance of a novel hypoxia-regulated marker, carbonic anhydrase IX, in invasive breast carcinoma. J Clin Oncol 2001, 19:3660-3668.

16. Generali D, Fox SB, Berruti A, Brizzi MP, Campo L, Bonardi S, Wigfield SM, Bruzzi P, Bersiga A, Allevi G, Milani M, Aguggini S, Dogliotti L, Bottini A, Harris AL: Role of carbonic anhydrase IX expression in prediction of the efficacy and outcome of primary epirubicin/tamoxifen therapy for breast cancer. Endocr Relat Cancer 2006, 13:921-930.

17. Eppenberger U, Kueng W, Schlaeppi JM, Roesel JL, Benz C, Mueller H, Matter A, Zuber M, Luescher K, Litschgi M, Schmitt M, Foekens JA, EppenbergerCastori S: Markers of tumor angiogenesis and proteolysis independently define high- and low-risk subsets of node-negative breast cancer patients. J Clin Oncol 1998, 16:3129-3136.

18. Gasparini G, Toi M, Gion M, Verderio P, Dittadi R, Hanatani M, Matsubara I, Vinante O, Bonoldi E, Boracchi P, Gatti C, Suzuki H, Tominaga T: Prognostic significance of vascular endothelial growth factor protein in nodenegative breast carcinoma. J Natl Cancer Inst 1997, 89:139-147.

19. Linderholm B, Grankvist K, Wilking N, Johansson M, Tavelin B, Henriksson R: Correlation of vascular endothelial growth factor content with recurrences, survival, and first relapse site in primary node-positive breast carcinoma after adjuvant treatment. J Clin Oncol 2000, 18:1423-1431.

20. Kang SS, Chun YK, Hur MH, Lee HK, Kim YJ, Hong SR, Lee JH, Lee SG, Park YK: Clinical significance of glucose transporter 1 (GLUT1) expression in human breast carcinoma. Jpn J Cancer Res 2002, 93:1123-1128.

21. Vleugel MM, Greijer AE, Shvarts A, van der Groep P, van Berkel M, Aarbodem Y, van Tinteren $H$, Harris $A L$, van Diest PJ, van der Wall E: Differential prognostic impact of hypoxia induced and diffuse HIF-1 a expression in invasive breast cancer. J Clin Pathol 2005, 58:172-177.

22. Giatromanolaki A, Sivridis E, Gatter KC, Turley H, Harris AL, Koukourakis MI: Lactate dehydrogenase $5(\mathrm{LDH}-5)$ expression in endometrial cancer relates to the activated VEGF/VEGFR2(KDR) pathway and prognosis. Gynecol Oncol 2006, 103:912-918.

23. Koukourakis MI, Giatromanolaki A, Simopoulos C, Polychronidis A, Sivridis E: Lactate dehydrogenase 5 (LDH5) relates to up-regulated hypoxia inducible factor pathway and metastasis in colorectal cancer. Clin Exp Metastasis 2005, 22:25-30.

24. Koukourakis MI, Giatromanolaki A, Sivridis E, Bougioukas G, Didilis V, Gatter 
$\mathrm{KC}$, Harris AL: Lactate dehydrogenase-5 (LDH-5) overexpression in nonsmall-cell lung cancer tissues is linked to tumour hypoxia, angiogenic factor production and poor prognosis. Br J Cancer 2003, 89:877-885.

25. Koukourakis MI, Giatromanolaki A, Sivridis E, Gatter KC, Harris AL: Lactate dehydrogenase 5 expression in operable colorectal cancer: strong association with survival and activated vascular endothelial growth factor pathway - a report of the Tumour Angiogenesis Research Group. J Clin Oncol 2006, 24:4301-4308.

26. Koukourakis MI, Giatromanolaki A, Winter S, Leek R, Sivridis E, Harris AL: Lactate dehydrogenase 5 expression in squamous cell head and neck cancer relates to prognosis following radical or postoperative radiotherapy. Oncology 2009, 77:285-292.

27. Koukourakis MI, Kontomanolis E, Giatromanolaki A, Sivridis E, Liberis V: Serum and tissue LDH levels in patients with breast/gynaecological cancer and benign diseases. Gynecol Obstet Invest 2009, 67:162-168.

28. Rademakers SE, Lok J, van der Kogel AJ, Bussink J, Kaanders JH: Metabolic markers in relation to hypoxia; staining patterns and colocalization of pimonidazole, HIF-1a, CAIX, LDH-5, GLUT-1, MCT1 and MCT4. BMC Cancer 2011, 11:167.

29. Wouters BG, Koritzinsky M: Hypoxia signalling through mTOR and the unfolded protein response in cancer. Nat Rev Cancer 2008, 8:851-864.

30. Brugarolas J, Lei K, Hurley RL, Manning BD, Reiling JH, Hafen E, Witters LA, Ellisen LW, Kaelin WG Jr: Regulation of mTOR function in response to hypoxia by REDD 1 and the TSC1/TSC2 tumor suppressor complex. Genes Dev 2004, 18:2893-2904.

31. Li Y, Wang Y, Kim E, Beemiller P, Wang CY, Swanson J, You M, Guan KL: Bnip3 mediates the hypoxia-induced inhibition on mammalian target of rapamycin by interacting with Rheb. J Bio/ Chem 2007, 282:35803-35813.

32. Land SC, Tee AR: Hypoxia-inducible factor $1 a$ is regulated by the mammalian target of rapamycin (mTOR) via an mTOR signaling motif. J Bio/ Chem 2007, 282:20534-20543.

33. Teicher BA: Hypoxia and drug resistance. Cancer Metastasis Rev 1994, 13:139-168.

34. Wilson WR, Hay MP: Targeting hypoxia in cancer therapy. Nat Rev Cancer, 11:393-410.

35. Unruh A, Ressel A, Mohamed HG, Johnson RS, Nadrowitz R, Richter E, Katschinski DM, Wenger $\mathrm{RH}$ : The hypoxia-inducible factor-1 a is a negative factor for tumor therapy. Oncogene 2003, 22:3213-3220.

36. Generali D, Berruti A, Brizzi MP, Campo L, Bonardi S, Wigfield S, Bersiga A, Allevi G, Milani M, Aguggini S, Gandolfi V, Dogliotti L, Bottini A, Harris AL, Fox SB: Hypoxia-inducible factor-1a expression predicts a poor response to primary chemoendocrine therapy and disease-free survival in primary human breast cancer. Clin Cancer Res 2006, 12:4562-4568.

37. Generali D, Buffa FM, Berruti A, Brizzi MP, Campo L, Bonardi S, Bersiga A, Allevi G, Milani M, Aguggini S, Papotti M, Dogliotti L, Bottini A, Harris AL, Fox SB: Phosphorylated ERa, HIF-1a, and MAPK signaling as predictors of primary endocrine treatment response and resistance in patients with breast cancer. J Clin Oncol 2009, 27:227-234.

38. Span PN, Bussink J, Manders P, Beex LV, Sweep CG: Carbonic anhydrase-9 expression levels and prognosis in human breast cancer: association with treatment outcome. Br J Cancer 2003, 89:271-276.

39. Sathornsumetee S, Cao Y, Marcello JE, Herndon JE 2nd, McLendon RE, Desjardins A, Friedman HS, Dewhirst MW, Vredenburgh JJ, Rich JN: Tumor angiogenic and hypoxic profiles predict radiographic response and survival in malignant astrocytoma patients treated with bevacizumab and irinotecan. J Clin Oncol 2008, 26:271-278.

40. Leitzel H, HH, Shrivastava V, Anyanwu U, Ali SM, Koestler W, Fuchs E, BrownShimer S, Carney W, Lipton A: Use of pretreatment serum CA9 (carbonic anhydrase 9) to predict PFS and survival in trastuzumab-treated metastatic breast cancer. J Clin Onco/ 2009, 27:11092.

41. Brown RS, Wahl RL: Overexpression of Glut-1 glucose transporter in human breast cancer. An immunohistochemical study. Cancer 1993, 72:2979-2985.

42. Rastogi S, Banerjee S, Chellappan S, Simon GR: Glut-1 antibodies induce growth arrest and apoptosis in human cancer cell lines. Cancer Lett 2007, 257:244-251.

43. Foekens JA, Peters HA, Grebenchtchikov N, Look MP, Meijer-van Gelder ME, Geurts-Moespot A, van der Kwast TH, Sweep CG, Klijn JG: High tumor levels of vascular endothelial growth factor predict poor response to systemic therapy in advanced breast cancer. Cancer Res 2001, 61:5407-5414.

44. Carmeliet P, Jain RK: Principles and mechanisms of vessel normalization for cancer and other angiogenic diseases. Nat Rev Drug Discov 2011,
10:417-427.

45. Mehta S, Hughes NP, Buffa FM, Li SP, Adams RF, Adwani A, Taylor NJ, Levitt NC, Padhani AR, Makris A, Harris AL: Assessing early therapeutic response to bevacizumab in primary breast cancer using magnetic resonance imaging and gene expression profiles. J Nat/ Cancer Inst 2011, in press.

46. Rapisarda A, Hollingshead M, Uranchimeg B, Bonomi CA, Borgel SD, Carter JP, Gehrs B, Raffeld M, Kinders RJ, Parchment R, Anver MR, Shoemaker RH, Melillo $\mathrm{G}$ : Increased antitumor activity of bevacizumab in combination with hypoxia inducible factor-1 inhibition. Mol Cancer Ther 2009, 8:1867-1877.

47. Winter SC, Buffa FM, Silva P, Miller C, Valentine HR, Turley H, Shah KA, Cox GJ, Corbridge RJ, Homer JJ, Musgrove B, Slevin N, Sloan P, Price P, West CM, Harris $\mathrm{AL}$ : Relation of a hypoxia metagene derived from head and neck cancer to prognosis of multiple cancers. Cancer Res 2007, 67:3441-3449.

48. Brown LM, Cowen RL, Debray C, Eustace A, Erler JT, Sheppard FC, Parker CA, Stratford IJ, Williams KJ: Reversing hypoxic cell chemoresistance in vitro using genetic and small molecule approaches targeting hypoxia inducible factor-1. Mol Pharmacol 2006, 69:411-418.

49. Rapisarda A, Uranchimeg B, Sordet O, Pommier Y, Shoemaker RH, Melillo G: Topoisomerase I-mediated inhibition of hypoxia-inducible factor 1: mechanism and therapeutic implications. Cancer Res 2004, 64:1475-1482

50. Rapisarda A, Zalek J, Hollingshead M, Braunschweig T, Uranchimeg B, Bonomi CA, Borgel SD, Carter JP, Hewitt SM, Shoemaker RH, Melillo G: Scheduledependent inhibition of hypoxia-inducible factor-1a protein accumulation, angiogenesis, and tumor growth by topotecan in U251HRE glioblastoma xenografts. Cancer Res 2004, 64:6845-6848.

51. Mackay H, Hedley D, Major P, Townsley C, Mackenzie M, Vincent M, Degendorfer P, Tsao MS, Nicklee T, Birle D, Wright J, Siu L, Moore M, Oza A: A phase II trial with pharmacodynamic endpoints of the proteasome inhibitor bortezomib in patients with metastatic colorectal cancer. Clin Cancer Res 2005, 11:5526-5533.

52. Koh MY, Spivak-Kroizman T, Venturini S, Welsh S, Williams RR, Kirkpatrick DL, Powis G: Molecular mechanisms for the activity of PX-478, an antitumor inhibitor of the hypoxia-inducible factor-1a. Mol Cancer Ther 2008, 7:90-100.

53. Li SH, Shin DH, Chun YS, Lee MK, Kim MS, Park JW: A novel mode of action of YC-1 in HIF inhibition: stimulation of FIH-dependent p300 dissociation from HIF-1a. Mol Cancer Ther 2008, 7:3729-3738.

54. Jones DT, Harris AL: Identification of novel small-molecule inhibitors of hypoxia-inducible factor-1 transactivation and DNA binding. Mol Cancer Ther 2006, 5:2193-2202

55. Jones DT, Pugh CW, Wigfield S, Stevens MF, Harris AL: Novel thioredoxin inhibitors paradoxically increase hypoxia-inducible factor-alpha expression but decrease functional transcriptional activity, DNA binding, and degradation. Clin Cancer Res 2006, 12:5384-5394.

56. Jones DT, Trowbridge IS, Harris AL: Effects of transferrin receptor blockade on cancer cell proliferation and hypoxia-inducible factor function and their differential regulation by ascorbate. Cancer Res 2006, 66:2749-2756.

57. Post DE, Sandberg EM, Kyle MM, Devi NS, Brat DJ, Xu Z, Tighiouart M, Van Meir EG: Targeted cancer gene therapy using a hypoxia inducible factor dependent oncolytic adenovirus armed with interleukin-4. Cancer Res 2007, 67:6872-6881.

58. Sun X, Vale M, Jiang X, Gupta R, Krissansen GW: Antisense HIF-1 a prevents acquired tumor resistance to angiostatin gene therapy. Cancer Gene Ther 2010, 17:532-540.

59. Tatum JL, Kelloff GJ, Gillies RJ, Arbeit JM, Brown JM, Chao KS, Chapman JD, Eckelman WC, Fyles AW, Giaccia AJ, Hill RP, Koch CJ, Krishna MC, Krohn KA, Lewis JS, Mason RP, Melillo G, Padhani AR, Powis G, Rajendran JG, Reba R, Robinson SP, Semenza GL, Swartz HM, Vaupel P, Yang D, Croft B, Hoffman J, Liu G, Stone H, et al:: Hypoxia: importance in tumor biology, noninvasive measurement by imaging, and value of its measurement in the management of cancer therapy. Int J Radiat Bio/ 2006, 82:699-757.

60. Postema EJ, McEwan AJ, Riauka TA, Kumar P, Richmond DA, Abrams DN, Wiebe LI: Initial results of hypoxia imaging using 1-alpha-D: -(5-deoxy-5[18F]-fluoroarabinofuranosyl)-2-nitroimidazole (18F-FAZA). Eur J Nucl Med Mol Imaging 2009, 36:1565-1573.

61. van Loon J, Janssen MH, Ollers M, Aerts HJ, Dubois L, Hochstenbag M, Dingemans AM, Lalisang $R$, Brans B, Windhorst B, van Dongen GA, Kolb H, Zhang J, De Ruysscher D, Lambin P: PET imaging of hypoxia using [18F] HX4: a phase I trial. Eur J Nucl Med Mol Imaging 2010, 37:1663-1668.

62. Chitneni SK, Palmer GM, Zalutsky MR, Dewhirst MW: Molecular imaging of hypoxia. J Nucl Med 2011, 52:165-168.

63. Buffa FM, Harris AL, West CM, Miller CJ: Large meta-analysis of multiple 
cancers reveals a common, compact and highly prognostic hypoxia metagene. Br J Cancer 2010, 102:428-435.

64. Chen JL, Lucas JE, Schroeder T, Mori S, Wu J, Nevins J, Dewhirst M, West M, Chi $J \mathrm{~T}$ : The genomic analysis of lactic acidosis and acidosis response in human cancers. PLoS Genet 2008, 4:e1000293.

65. Chi JT, Wang Z, Nuyten DS, Rodriguez EH, Schaner ME, Salim A, Wang Y, Kristensen GB, Helland A, Borresen-Dale AL, Giaccia A, Longaker MT, Hastie T, Yang GP, van de Vijver MJ, Brown PO: Gene expression programs in response to hypoxia: cell type specificity and prognostic significance in human cancers. PLoS Med 2006, 3:e47.

66. Nuyten DS, Kreike B, Hart AA, Chi JT, Sneddon JB, Wessels LF, Peterse HJ, Bartelink H, Brown PO, Chang HY, van de Vijver MJ: Predicting a local recurrence after breast-conserving therapy by gene expression profiling. Breast Cancer Res 2006, 8:R62.

67. Seigneuric R, Starmans MH, Fung G, Krishnapuram B, Nuyten DS, van Erk A, Magagnin MG, Rouschop KM, Krishnan S, Rao RB, Evelo CT, Begg AC, Wouters $B G$, Lambin P: Impact of supervised gene signatures of early hypoxia on patient survival. Radiother Oncol 2007, 83:374-382.

68. Favaro E, Ramachandran A, McCormick R, Gee H, Blancher C, Crosby M, Devlin C, Blick C, Buffa F, Li JL, Vojnovic B, Pires das Neves R, Glazer P, Iborra F, Ivan M, Ragoussis J, Harris AL: MicroRNA-210 regulates mitochondrial free radical response to hypoxia and Krebs cycle in cancer cells by targeting iron sulfur cluster protein ISCU. PLoS One 2010, 5:e10345.

69. Bartel DP: MicroRNAs: target recognition and regulatory functions. Cell 2009, 136:215-233.

70. Filipowicz W, Bhattacharyya SN, Sonenberg N: Mechanisms of posttranscriptional regulation by microRNAs: are the answers in sight? Nat Rev Genet 2008, 9:102-114

71. Ambros V: The functions of animal microRNAs. Nature 2004, 431:350-355

72. Ventura A, Jacks T: MicroRNAs and cancer: short RNAs go a long way. Cell 2009, 136:586-591

73. Buffa FM, Camps C, Winchester L, Snell CE, Gee HE, Sheldon H, Taylor M, Harris AL, Ragoussis J: microRNA associated progression pathways and potential therapeutic targets identified by integrated mRNA and microRNA expression profiling in breast cancer. Cancer Res 2011. doi: 10.1158/00085472. CAN-11-0489.

74. Foekens JA, Sieuwerts AM, Smid M, Look MP, de Weerd V, Boersma AW, Klijn $J G$, Wiemer EA, Martens JW: Four miRNAs associated with aggressiveness of lymph node-negative, estrogen receptor-positive human breast cancer. Proc Natl Acad Sci U S A 2008, 105:13021-13026.

75. Iorio MV, Casalini P, Tagliabue E, Menard S, Croce CM: MicroRNA profiling as a tool to understand prognosis, therapy response and resistance in breast cancer. Eur J Cancer 2008, 44:2753-2759.

76. Iorio MV, Ferracin M, Liu CG, Veronese A, Spizzo R, Sabbioni S, Magri E, Pedriali M, Fabbri M, Campiglio M, Menard S, Palazzo JP, Rosenberg A, Musiani P, Volinia S, Nenci I, Calin GA, Querzoli P, Negrini M, Croce CM: MicroRNA gene expression deregulation in human breast cancer. Cancer Res 2005 65:7065-7070

77. Camps C, Buffa FM, Colella S, Moore J, Sotiriou C, Sheldon H, Harris AL, Gleadle JM, Ragoussis J: hsa-miR-210 Is induced by hypoxia and is an independent prognostic factor in breast cancer. Clin Cancer Res 2008, 14:1340-1348

78. Kulshreshtha R, Ferracin M, Wojcik SE, Garzon R, Alder H, Agosto-Perez FJ, Davuluri R, Liu CG, Croce CM, Negrini M, Calin GA, Ivan M: A microRNA signature of hypoxia. Mol Cell Bio/ 2007, 27:1859-1867.

79. Chan SY, Loscalzo J: MicroRNA-210: a unique and pleiotropic hypoxamir Cell Cycle 2010, 9:1072-1083.

80. Crosby ME, Kulshreshtha R, Ivan M, Glazer PM: MicroRNA regulation of DNA repair gene expression in hypoxic stress. Cancer Res 2009, 69:1221-1229.

81. Fasanaro P, D'Alessandra Y, Di Stefano V, Melchionna R, Romani S, Pompilio G, Capogrossi MC, Martelli F: MicroRNA-210 modulates endothelial cell response to hypoxia and inhibits the receptor tyrosine kinase ligand Ephrin-A3. J Biol Chem 2008, 283:15878-15883.

82. Giannakakis A, Sandaltzopoulos R, Greshock J, Liang S, Huang J, Hasegawa K Li C, O'Brien-Jenkins A, Katsaros D, Weber BL, Simon C, Coukos G, Zhang L: miR-210 links hypoxia with cell cycle regulation and is deleted in human epithelial ovarian cancer. Cancer Biol Ther 2008, 7:255-264.

83. Huang X, Ding L, Bennewith KL, Tong RT, Welford SM, Ang KK, Story M, Le QT, Giaccia AJ: Hypoxia-inducible mir-210 regulates normoxic gene expression involved in tumor initiation. Mol Cell 2009, 35:856-867.

84. Kim HW, Haider HK, Jiang S, Ashraf M: Ischemic preconditioning augments survival of stem cells via miR-210 expression by targeting caspase-8associated protein 2. J Biol Chem 2009, 284:33161-33168.

85. Puissegur MP, Mazure NM, Bertero T, Pradelli L, Grosso S, Robbe-Sermesant K, Maurin T, Lebrigand K, Cardinaud B, Hofman V, Fourre S, Magnone V, Ricci JE, Pouyssegur J, Gounon P, Hofman P, Barbry P, Mari B: miR-210 is overexpressed in late stages of lung cancer and mediates mitochondrial alterations associated with modulation of HIF-1 activity. Cell Death Differ 2010, 18:465-478.

86. Tsuchiya S, Fujiwara T, Sato F, Shimada Y, Tanaka E, Sakai Y, Shimizu K, Tsujimoto G: MicroRNA-210 regulates cancer cell proliferation through targeting fibroblast growth factor receptor-like 1 (FGFRL1). J Biol Chem 2010, 286:420-428.

87. Zhang Z, Sun H, Dai H, Walsh RM, Imakura M, Schelter J, Burchard J, Dai X, Chang AN, Diaz RL, Marszalek JR, Bartz SR, Carleton M, Cleary MA, Linsley PS, Grandori C: MicroRNA miR-210 modulates cellular response to hypoxia through the MYC antagonist MNT. Cell Cycle 2009, 8:2756-2768.

88. Hwang-Verslues WW, Chang PH, Wei PC, Yang CY, Huang CK, Kuo WH, Shew $J Y$, Chang KJ, Lee EY, Lee WH: miR-495 is upregulated by E12/E47 in breast cancer stem cells, and promotes oncogenesis and hypoxia resistance via downregulation of E-cadherin and REDD1. Oncogene 2011, 30:2463-2474.

89. Lawrie CH, Gal S, Dunlop HM, Pushkaran B, Liggins AP, Pulford K, Banham AH, Pezzella F, Boultwood J, Wainscoat JS, Hatton CS, Harris AL: Detection of elevated levels of tumour-associated microRNAs in serum of patients with diffuse large B-cell lymphoma. Br J Haemato/ 2008, 141:672-675.

90. Schindl M, Schoppmann SF, Samonigg H, Hausmaninger H, Kwasny W, Gnant M, Jakesz R, Kubista E, Birner P, Oberhuber G: Overexpression of hypoxiainducible factor $1 \mathrm{a}$ is associated with an unfavorable prognosis in lymph node-positive breast cancer. Clin Cancer Res 2002, 8:1831-1837.

91. Trastour C, Benizri E, Ettore F, Ramaioli A, Chamorey E, Pouyssegur J, Berra E: HIF-1a and CAIX staining in invasive breast carcinomas: prognosis and treatment outcome. Int J Cancer 2007, 120:1451-1458.

92. Bos R, van der Groep P, Greijer AE, Shvarts A, Meijer S, Pinedo HM, Semenza GL, van Diest PJ, van der Wall E: Levels of hypoxia-inducible factor-1a independently predict prognosis in patients with lymph node negative breast carcinoma. Cancer 2003, 97:1573-1581.

93. Gruber G, Greiner RH, Hlushchuk R, Aebersold DM, Altermatt HJ, Berclaz G, Djonov V: Hypoxia-inducible factor 1a in high-risk breast cancer: an independent prognostic parameter? Breast Cancer Res 2004, 6:R191-198.

94. Yamamoto Y, Ibusuki M, Okumura Y, Kawasoe T, Kai K, lyama K, Iwase H: Hypoxia-inducible factor $1 \mathrm{a}$ is closely linked to an aggressive phenotype in breast cancer. Breast Cancer Res Treat 2008, 110:465-475

95. Schoppmann SF, Fenzl A, Schindl M, Bachleitner-Hofmann T, Nagy K, Gnant $M$, Horvat R, Jakesz R, Birner P: Hypoxia inducible factor-1a correlates with VEGF-C expression and lymphangiogenesis in breast cancer. Breast Cancer Res Treat 2006, 99:135-141

96. Dales JP, Garcia S, Meunier-Carpentier S, Andrac-Meyer L, Haddad O, Lavaut MN, Allasia C, Bonnier P, Charpin C: Overexpression of hypoxia-inducible factor HIF-1 a predicts early relapse in breast cancer: retrospective study in a series of 745 patients. Int J Cancer 2005, 116:734-739.

97. Helczynska K, Larsson AM, Holmquist Mengelbier L, Bridges E, Fredlund E, Borgquist S, Landberg G, Pahlman S, Jirstrom K: Hypoxia-inducible factor-2a correlates to distant recurrence and poor outcome in invasive breast cancer. Cancer Res 2008, 68:9212-9220.

98. Massard C, Gomez-Roca CA, Bahleda R, Nguyen VDh B, Besse-Hammer T Awada A, Soria J: Phase I accelerated dose-escalating safety and pharmacokinetic (PK) study of aryl-hydrocarbon receptor-mediated aminoflavone prodrug AFP464 in advanced solid tumors. J Clin Onco/ 2010, 28 (S15 suppl):abstract 2561.

99. Marshall ME, Wolf MK, Crawford ED, Taylor S, Blumenstein B, Flanigan R, Meyers FJ, Hynes HE, Barlogie B, Eisenberger M: Phase II trial of echinomycin for the treatment of advanced renal cell carcinoma. A Southwest Oncology Group study. Invest New Drugs 1993, 11:207-209.

100. Erlichman C, Toft D, Reid J, Goetz M, Ames M, Mandrekar S, Ajei A, McCollum A, Ivy P: A phase I trial of 17-allylamino-geldanamycin (17AAG) in patients with advanced cancer. J Clin Oncol 2004, 22 (14S suppl):abstract 3030.

101. Vaishampayan UN, Sausville E, Heilbrun LK, Quinn M, Burger A, Ivy P, Li J, Heath E, Lorusso P: Phase I trial of oral sorafenib $(B)$ and intravenous 17-allyl-amino-geldanamycin (A) in advanced malignancies: safety and efficacy in metastatic renal cancer (RCC). In 2008 Genitourinary Cancers Symposium, San Francisco, Abstract and Poster Presentation: abstract 368 102. Tibes R, Falchook G, Von Hoff DD, Weiss GJ, Iyengar T, Kurzrock R, Pestano L, 
Lowe AM, Herbst R: Results from a phase I, dose-escalation study of PX-478, an orally available inhibitor of HIF-1a. J Clin Oncol 2010, 28 (S15 suppl):abstract 3076.

103. Buffa FM, Bentzen SM, Daley FM, Dische S, Saunders MI, Richman PI, Wilson GD: Molecular marker profiles predict locoregional control of head and neck squamous cell carcinoma in a randomized trial of continuous hyperfractionated accelerated radiotherapy. Clin Cancer Res 2004, 10:3745-3754.

104. Pulkkinen K, Malm T, Turunen M, Koistinaho J, Yla-Herttuala S: Hypoxia induces microRNA miR-210 in vitro and in vivo ephrin-A3 and neuronal pentraxin 1 are potentially regulated by miR-210. FEBS Lett 2008, 582:2397-2401.

105. Mizuno Y, Tokuzawa Y, Ninomiya Y, Yagi K, Yatsuka-Kanesaki Y, Suda T, Fukuda T, Katagiri T, Kondoh Y, Amemiya T, Tashiro H, Okazaki Y: miR-210 promotes osteoblastic differentiation through inhibition of AcvR1b. FEBS Lett 2009, $583: 2263-2268$
106. Fasanaro P, Greco S, Lorenzi M, Pescatori M, Brioschi M, Kulshreshtha R, Banfi C, Stubbs A, Calin GA, Ivan M, Capogrossi MC, Martelli F: An integrated approach for experimental target identification of hypoxia-induced miR-210. J Biol Chem 2009, 284:35134-35143.

107. Chan SY, Zhang YY, Hemann C, Mahoney CE, Zweier JL, Loscalzo J: MicroRNA-210 controls mitochondrial metabolism during hypoxia by repressing the iron-sulfur cluster assembly proteins ISCU1/2. Cell Metab 2009, 10:273-284.

108. Chen Z, LiY, Zhang H, Huang P, Luthra R: Hypoxia-regulated microRNA-210 modulates mitochondrial function and decreases ISCU and COX10 expression. Oncogene 2010, 29:4362-4368.

doi:10.1186/gm271

Cite this article as: Favaro E, et al.: Gene expression and hypoxia in breast cancer. Genome Medicine 2011, 3:55. 